\title{
Specialized Discounted Cash Flow Analysis Formulas for Valuation of Benefits and Costs of Urban Trees and Forests
}

\author{
Kristin S. Peterson and Thomas J. Straka
}

\begin{abstract}
Urban trees and forests have distinct benefits and costs that can be evaluated financially. While there are appraisal methods commonly used to value individual trees and urban forests, one method that is difficult to use in practice is a discounted cash flow (DCF) analysis. This is the appraisal method that best accounts for the time value of money and allows for a temporal comparison of benefits and costs. Current timber appraisal methods are discussed for urban situations and DCF analysis is presented as a viable supplemental appraisal method for valuation of the urban trees. Simple models are presented that allow for the solution of DCF-type urban forestry valuations using conventional software valuation packages. Examples are provided of typical urban tree benefit and cost scenarios, with DCF calculations of present value (PV) and net present value using the specialized DCF formulas.

Key Words. Appraisal; Discount Rate; Discounted Cash Flow Analysis; Financial; Net Present Value; Present Value; Urban Forestry; Valuation.
\end{abstract}

Discounted cash flow (DCF) analysis is a method of valuation often used in forests managed for timber production objectives, to obtain the present value (PV) of cash flows or the value in current day currency (e.g., U.S. dollars) considering interest (Bullard and Straka 1998). Several conventional forestry valuation software packages use DCF as a method for financial decision-making because it accounts for the time value of money and represents the dynamic financial nature of a timber stand. Early forest valuation models, such as Faustmann's formula, rely on the principles of DCF analysis to determine important forestry investment financial criteria, such as land expectation value, and financial optima, like rotation length (Tietenberg and Lewis 2008). DCF analysis produces reliable monetary valuations for natural resources, including forests (Gollier et al. 2008; Kanniainen 2009). DCF is often used over long spans of time with good results; however, its use to value long-life assets, like trees, may produce concerns, such as fairness to future generations and inflation estimates (Price 2005).

Despite its accepted use in forestry for timber production, DCF analysis, or the income approach in general, has not been frequently used in urban forestry and arboriculture. Cash flows for the benefits and costs of single trees or urban forests are difficult to determine, and the mathematical structure of DCF analysis is somewhat complicated (Council of Tree and Landscape Appraisers 2000; Straka and Bullard 2006). Negative cash flows or expenditures (both capital and operating) are called "costs" in traditional forestry investment analysis, but they are more likely to be labeled as "expenses" in an appraisal income approach. Conventional forestry valuation software packages (such as Forest Valuation-forestry investment calculations, or FORVAL) can be used for DCF calculations, but they require that cash flows be input in one of a few standard structures (e.g., single sum, terminating annuity, perpetual annuity, or perpetual periodic series) (Straka and Bullard 2002). These standard structures have rigid assumptions about the cash flow sequences; for example, a cash flow occurring each year and beginning at year 1 , or a cash flow occurring periodically every X years and beginning at year X (Straka and Bullard 2002). Benefits (i.e., income) and costs in urban forest and tree valuation situations do not always occur in these structured patterns. Standard DCF formulas do not handle irregular cash flows well. This is another primary reason the income approach is often difficult to apply in these situations (Bullard and Straka 2006).

\section{STUDY METHODS}

The study authors identified a series of specialized discounting formulas that were well-suited for solving valuation problems that follow typical cash flow patterns occurring in the benefit and cost structures of urban tree and forest situations. That is to clarify, valuation problems that do not follow standard structured cash flow patterns and, thus, would be difficult to value using many conventional DCF formulas (McPherson and Simpson 2002; McPherson 2003; McPherson 2007). Using the standard DCF formulas common to forest valuation (Appraisal Institute 2008, Bullard and Straka 1998) as a foundation, a series of new or "special" DCF formulas that will allow these benefit and cost situations to be evaluated were constructed using conventional DCF valuation software packages. Simple hypothetical examples of the individual benefit and cost valuations were developed. The study authors also reviewed the basic, standard DCF formulas as they are the basis of these specialized formulas. Most formulas could be utilized as part of a standard DCF valuation software models, like FORVAL (Straka and Bullard 2006; Bullard et al. 2011).

First, for the current study, three fairly standard formulas were presented. Next, a few unusual, but standard formulas were described that have application to urban situations. Finally, some unique DCF formulas were derived for typical urban tree and forest situations that usually don't allow for direct PV calculations using traditional DCF valuation software 
packages. Later, examples of urban tree and forest valuation situations representing applications of each formula were illustrated via detailed calculations as to their use in DCF analyses.

The use of each formula was illustrated using arboriculture and urban forestry examples, like carbon sequestration, energy savings, windbreak savings, windbreaks, soil enhancement, and maintenance costs. The examples were developed from actual urban forest and single tree benefits and costs identified in the literature. Many of the benefit estimates from the current study came from the National Tree Benefit Calculator (Casey Trees and Davey Tree Expert Company 2009) and many of the costs from Atlanta Tree Service at Cost (ATSC 2011). The consumer price index (or the inflation rate) was used to adjust costs or benefits from previous studies to current levels (U.S. Dept. of Labor 2011). However, the goal of the study authors was not to provide real world, current estimates of urban tree and forest benefits and costs. Rather, to provide simplified situations to better explain their usage. The study authors included calculations of both the PV and the urban tree site value (UTSV) to show the application of both.

\section{Single-sum Discounting (SSD)}

The basic formula used in DCF analysis is the formula for discounting a single sum. Costs of tree removal, for example, occur only once in the lifecycle of a tree and are, thus, single sums and discounted with the SSD formula. It discounts a cash flow to year zero on a cash flow timeline. Year zero represents the current point in time or the beginning of year one or time period one. This formula is

$$
V_{0}=\frac{V_{n}}{(1+i)^{n}}
$$

where $V_{0}$ is the value at year zero, $V_{n}$ is the value at year $n, i$ is the interest rate (expressed as a decimal), and $n$ is the number of years being evaluated.

\section{Present Value of a Terminating Annuity (TA)}

Sometimes cash flows of the same magnitude occur annually. An example may be annual maintenance costs for a population of trees with a constant mix of age classes. A basic formula calculates the present value of a terminating annual series as

$$
V_{0}=a \frac{(1+i)^{n}-1}{i(1+i)^{n}}
$$

where $a$ is the annual cash flow and the remaining variables are as previously defined.

\section{Present Value of a Perpetual Annuity (PA)}

In some urban forestry situations (such as the creation of a conservation easement that generates perpetual uniform benefits over time), the value of an annual cash flow occurs forever. The calculation of a perpetual annuity is as follows

$$
V_{0}=\frac{a}{i}
$$

where $a$ is the annual cash flow and the remaining variables are as previously defined.
Present Value of a Terminating Periodic Series (TPS) The prior valuation formulas were basic DCF analysis tools. Most valuation software packages include an automatic computation of these values. The TPS formula is not a basic DCF formula. Terminating periodic refers to a situation where benefits or costs have a regular, uniform magnitude, but occur on a periodic, not an annual basis. An example would be stormwater or flood mitigation every 20 years, starting at year 20 and ending at year 140. The formula could easily be adapted to time periods shorter than a year. The TPS formula is

$$
V_{0}=a \frac{(1+i)^{n t}-1}{\left[(1+i)^{t}-1\right](1+i)^{n t}}
$$

where $t$ is the length of each period in years, $n$ is the number of compounding periods, and the remaining variables are as previously defined.

\section{Present Value of a Fixed Rate Increasing Annuity (FRIA)}

In other situations, benefits or costs may occur annually but have a magnitude that increases at an exponential rate. For example, a tree's ability to sequester carbon may increase a given rate per year. In this case, an arborist can use a formula for the present value of a growing annuity. The calculation of the FRIA is:

$$
V_{0}=\frac{a}{(i-g)}\left[1-\left(\frac{1+g}{1+i}\right)^{n}\right]
$$

where $g$ is the percentage rate of growth of the annuity (expressed as a decimal) and the remaining variables are as previously defined.

\section{Present Value of Minimum Size Delayed Annual Cash Flows (MSDACF)}

In some urban trees, annual cash flows may not occur until the tree reaches a certain minimum size. For example, electricity savings in summer from the shade of a large tree do not begin until the tree reaches a certain size. Other examples might be privacy benefits, sound barrier benefits, air quality, health, and recreation benefits (Ulrich 1984; Martin et al. 1989; Novak et al. 2002; Wolf 2004). In fact, MSDACF valuation is common in urban forestry applications, as many urban forest benefits rely on a certain crown size or structure more than a particular age or diameter at breast height. These crown assets only occur once the tree has reached a minimum age for developing a mature crown. The MSDACF formula is

$$
V_{0}=a \frac{(1+i)^{n_{a}}-1}{i(1+i)^{n_{a}}(1+i)^{n_{a}}}
$$

where $n_{a}$ is the number of years for which the annuity occurs and $n_{v}$ is the number of years the annuity is delayed from the standard annuity. The study authors note that this formula also applies to costs with similar financial scheduling, like periodic costs for pruning.

\section{Present Value of Minimum Size Delayed Periodic Cash Flows (MSDPCF)}

Similar to the MSDACF, the MSDPCF calculates the present value of benefits (or costs) incurred periodically that are 
contingent upon the tree reaching a certain "minimum size." An example would be the "windbreak" ability of a tree in a windstorm. First, the tree would need to reach a minimum size to have windbreak ability and second, the benefit would occur periodically, not every year. The MSDPCF formula is

$$
V_{0}=a \frac{(1+i)^{n_{a} t}-1}{\left[(1+i)^{t}-1\right](1+i)^{n_{a} t}(1+i)^{n v}}
$$

where $n_{t} t$ is the number of years for which the series occurs, $t$ is the length of the time period, and $n_{v}$ is the number of years in the future the series begins.

\section{Present Value of Patterned Terminating Periodic Series (PTPS)}

Urban trees may have several systematic, "stacked" cash flows, where one cash flow is "stacked" onto another. A cash flow of a smaller magnitude (i.e., the base series) may occur on a frequent basis, but necessitate a cash flow of a larger magnitude (i.e., the stacked series) on an infrequent basis. An example would be the soil enhancement benefit of trees. Fertilization might be reduced on an annual basis (the base series) and soil aeration might be reduced every 10 years (i.e., the stacked series). In this case, the larger cash flow is stacked onto the pattern of the smaller cash flow, and the following formula should be used:

$$
\begin{aligned}
V_{0} & =a_{1} \frac{(1+i)^{n_{1} t_{1}}-1}{\left[(1+i)^{t_{1}}-1\right](1+i)^{n_{1} t_{1}}} \\
& -\left(a_{2}-a_{1}\right) \frac{(1+i)^{n_{2} t_{2}}-1}{\left[(1+i)^{t_{2}}-1\right](1+i)^{n_{2} t_{2}}}
\end{aligned}
$$

where $a_{1}$ is the cash flow of the base series, $a_{2}$ is the cash flow of the stacked series, $i$ is the interest rate, $n_{1}$ is number of years the base series occurs, $t_{1}$ is the length of the time period for the base series, $n_{2}$ is the number of years the stacked series occurs, and $t_{2}$ is the length of the time period for the stacked series.

\section{Present Value of Minimum Size Delayed Pat- terned Terminating Cash Flows (MSDPTCF)}

Like other benefits or costs that do not begin until a minimum tree size is reached, patterned terminating benefits or costs need be discounted back to year zero. A systematic pruning of a tree on two levels is an example of this calculation; for example, minor pruning every five years and major pruning every twenty years. If so, the following formula should be used

$$
\begin{aligned}
V_{0} & =a_{1} \frac{(1+i)^{n_{1} t_{1}}-1}{\left[(1+i)^{t_{1}}-1\right](1+i)^{n_{1} t_{1}}(1+i)^{n_{v 1}}} \\
& -\left(a_{2}-a_{1}\right) \frac{(1+i)^{n_{2} t_{2}}-1}{\left[(1+i)^{t_{2}}-1\right](1+i)^{n_{2} t_{2}}(1+i)^{n_{v 2}}}
\end{aligned}
$$

where $a_{1}$ is the cash flow of the base series, $a_{2}$ is the cash flow of the stacked series, $n_{1}$ is the number of years for which the base series occurs, $t_{1}$ is the length of the time period for the base series, and $n_{2}$ is the number of years the stacked series occurs, $t_{2}$ is the length of the time period for the stacked series, $n_{v 1}$ is the number of years the base annuity is away from year zero, and $n_{v 2}$ is the number of years the stacked annuity is away from year zero.

\section{Urban Tree Site Value (UTSV)}

In traditional forestry literature, land expectation value, or bare land, value is calculated for land in permanent timber production (Klemperer 1996). This methodology can be used to calculate the PV of any perpetual cash flow-producing investment (Straka and Bullard 1996). This means a site value for an urban tree can also be calculated by compounding the PV of the tree's cash flows to the end of its rotation (defined as its viable life on the site) and assessing this over a perpetual time frame. The following formula accomplishes this:

$$
U T S V=\frac{P V(1+i)^{n}}{(1+i)^{n}-1}
$$

where UTSV is the urban tree site value with a perpetual time horizon, while present value is the present value of all benefits and costs of the tree for one rotation, and $n$ is the length of the rotation.

\section{Other Available Constructions}

Other formulas can be applied to urban tree cash flow analysis as well. For example, definite integration of discounted linear or nonlinear functions can show PV of cash flows with a functional increase or decrease over a particular period of time (Sartoris and Hill 1983). Sound barrier benefits are an example of this. Transition matrices can be used to calculate risk, given that certain information about the probability of risk is specified (Kaye and Pyke 2003). Marginal analysis can be used to look at the cumulative effect of cash flows with the same time series to reduce the overall number of DCF calculations (White et al. 1998).

\section{RESULTS}

A series of examples was developed to illustrate the use of both standard and specialized valuation formulas. To standardize the models, the examples were developed around a planted white oak (Quercus alba) in Atlanta, Georgia, U.S. It is estimated that a planted white oak has a lifespan of about 120 years, during the first 90 of which it is structurally sound (Burns and Honkala 1990). White oak trees reach a size of significant canopy coverage around 10 years of age. Thus, energy savings for the white oak begins at age 10. In 2010, the nursery price, plus planting, for white oak was USD \$70. For simplicity later in discussion, this will be called the "planting cost." Tree removal was assumed to cost $\$ 406$ for a tree greater than $60.96 \mathrm{~cm}$ in diameter (ATSC 2011). Tree removal will be in real terms and not increased with inflation. All of the figures were calculated at a 5\% real discount rate. This is a reasonable discount rate based on past consumer price index data (U.S. Dept. of Labor 2011).

\section{Five Standard Formulas (SSD, TA, PA, TPS, and UTSV)}

The five formulas are regularly used in urban tree and forest valuation by appraisers using the income approach (McPherson 2007). All have an assumption that the first payment is at the end of the first year or time period. Annual and periodic payments or benefits are assumed to occur at the end of the first year or time period, respectively. A key characteristic of the "special" formu- 
las is that the timing of the first payment often differs from this standard case. In a nonstandard or special case, an annual series first payment may be, for example, at year 10 instead of year one. Or a periodic series of payments every 20 years, for example, may have a first payment at year 35 instead of year 20. The discounting formulas often account for a first payment that occurs earlier or later than assumed in the standard formula situation.

A simple example using a 5\% interest rate was used to illustrate the use of each formula (Table 1). A planting cost of $\$ 70$ occurs at year zero (the present) and a one-time removal cost of $\$ 406$ occurs at year 90 . These are single sum problems, using Formula 1 the present values of the planting and removal costs are $\$ 70$ and $\$ 5.03$, respectively. Trees around a residence enhance privacy and provide additional home security protection; the study authors assumed this tree's benefit was worth a uniform $\$ 90$ per year. This benefit lasted for the average expected lifetimes of existing trees, or 90 years. This would be a terminating annuity problem; using Formula 2, the present value of these annual benefits was $\$ 1,777.70$. Another benefit might occur every 10 years; for example, stormwater mitigation, starting at year 10 and ending at year 90. This would be a terminating periodic series and would be solved with Formula 4 to produce a value of $\$ 314.07$. Finally, it was assumed that the tree increased property taxes by $\$ 10$, and that this cost would last in perpetuity. This cash flow was valued at $\$ 200$ with Formula 3. Note that the cash flows are summed in the Table. A sum of an investment's discounted benefits and costs is a net present value (NPV). The UTSV was the value of the same tree onsite on a perpetual basis, rather than just one 90 -year lifetime.

\section{Carbon Sequestration (FRIA and PA Calculations)}

The carbon sequestration ability of a tree increases as its size increases. Eventually, the tree reaches a maximum size but is still sequestering carbon. If the rate of sequestration is known, and increases at a geometric rate, the present value of the cash flow series can be calculated using Formula 5. Table 2 shows a simplified scenario for carbon sequestration; in the first year the benefit is $\$ 1$, and this value increases by $4 \%$ annually until age 70 . The study authors assumed that after age 70 the tree's growth becomes negligible, but used the age 70 value to represent carbon sequestration for the rest of perpetuity (because even after removal, the tree will still hold a fixed amount of carbon, assuming it ends up in building products or some other permanent use). The study authors used Formula 3 to value benefits past age 70. The FRIA calculation was the present value of a $\$ 1$ benefit that increased $4 \%$ annually to be worth $\$ 15.57$ at age 70 . The value of all the benefits past age 70 is $\$ 311.40$ (Formula 3), but that value must be discounted for 70 years and becomes a present value of $\$ 10.23$. Carbon sequestrating in this example produces a benefit of $\$ 59.05$.

\section{Energy Savings (MSDACF Calculation)}

American Forests (2001) showed that in Atlanta, GA, 0.4 ha of land with tree coverage would reduce natural gas usage by $\$ 13.67$. A tree must reach a certain minimum size before its crown is able to provide shade. In the provided example (Table 3 ), the designated minimum size is reached at year 10. Both planting costs and removal costs were single sums. Single sums were discounted using Formula 1. The annual savings represented a terminating annual series and were discounted using the standard formula for the present value of a terminating annual series to a present value of \$268.14 (Bullard and Straka 1998). However, since the first savings occur at the beginning of year 10 , the $\$ 268.14$ must be discounted for nine years and then become a present value at year 0 of $\$ 172.74$. Formula 6 allowed for the delayed annual series to be directly calculated as a PV of $\$ 172.74$. The "special case" formula simplified the calculation and required only a single formula. Note that PV was the value of a tree over a single lifetime and UTSV was the value of that same tree on a perpetual basis.

Table 1. Illustration of standard discounting formulas at a $5 \%$ interest rate. Formulas used include single sum discounting (SDS), terminating annuity (TA), perpetual annuity (PA), terminating periodic series (TPS), and urban tree site value (UTSV). Currency is in U.S. dollars.

\begin{tabular}{lllr}
\hline Treatment & Frequency & Years & Amount $(\$)$ \\
\hline Plant tree & Single time & 0 & $(70.00)$ \\
Annual benefit & Annual & $1-90$ & 90.00 \\
Periodic benefit & Every ten years & $10,20, \ldots 90$ & 200.00 \\
Perpetual cost & Annual & $1,2,3, \ldots \infty$ & $(10.00)$ \\
Remove tree & Single time & 90 & $(40.00)$ \\
& & & $(200.00)$ \\
Net present value (over 90 years) & & & $(5.03)$ \\
UTSV (in perpetuity) & & $1,816.74$ \\
\hline
\end{tabular}

Table 2. Carbon sequestration model at a $5 \%$ interest rate illustrating fixed rate increasing annuity (FRIA) and perpetual annuity (PA). Currency is in U.S. dollars.

\begin{tabular}{lllc}
\hline Item & Frequency & Years & Amount (\$) \\
\hline Plant tree & Single time & 0 & $(70.00)$ \\
Sequester & Annual & $1-70$ & $1.00-15.57$ \\
Sequester & Annual & $70+$ & 15.57 \\
Remove tree & Single time & 90 & $(70.00)$ \\
Net present value (over 90 years) & & & 48.82 \\
UTSV & & & $(406.00)$ \\
\hline
\end{tabular}




\section{Windbreak Savings (MSDPCF Calculation)}

The presence of a large oak on the lawn may stop the removal of shingles from a windstorm that occurs once every 10 years (Table 4). An approximation of cost savings (per 10 years) in this situation was $\$ 150$. This represented the cost (in time, labor, and materials) of replacing the shingles on the home. The study authors thus assumed the first windstorm occurred in year 15 , then every 10 years thereafter until year 85 . Again, tree planting and tree removal are single sums and Formula 1 was used to obtain a present value. Wind savings were trickier. The present value of a terminating periodic series of $\$ 150$ every 10 years, for 80 years, is $\$ 233.70$. The standard period annuity would have a first payment at year 10 , instead of year 15 , so the $\$ 233.70$ needed to be discounted for five years to obtain the correct PV of $\$ 183.11$. The same value can be calculated using Formula 7; the annuity occurs for 80 years, the length of the time period is 10 years, and the first payment is delayed by five years. Using those same three variable values, Formula 7 provides a PV of $\$ 183.11$.

\section{Soil Enhancement (PTPS Calculation)}

On lots without trees, treatments for soil, such as aeration, sod, and fertilization, are used to keep the soil lush. Sodding, aera- tion, and fertilization costs can be significant (Ocone 2000). Assume the soil (without trees) needs annual fertilization, sodding, and aeration once every 10 years and that the cost savings on sod and aeration, as well as fertilizer, were calculated as benefits (Table 5). Because fertilizer cost is stacked onto the base cost of sod and aeration, this was a patterned terminating series and Formula 8 can be used. Note that the fertilizer cost was stacked onto the base cost of sod and aeration. The pattern was illustrated in detail to better show how the formula could be used to solve for a present value (Table 5). Fertilization, sod, and aeration benefits were increased after year 30 to show an increase as the tree matures, which illustrates the formula's complexity.

\section{Maintenance Costs (MSDPTCF Calculation)}

There were costs to maintain trees on a site. For example, a crew works for five hours with three men (paid $\$ 10$ per hour) pruning a crapemyrtle (Lagerstroemia indicate) once every year. Transportation cost to the site and back is $\$ 10$. This occurred at the beginning of year 20 until year 90 . The PV was shown to be $\$ 1,226.72$ (Table 6). In some cases, this pruning cost will not be as easy to calculate. If one supposes this tree is the white oak and a minor pruning occurs once every five years for a cost of

Table 3. Energy savings model at a $5 \%$ interest rate illustrating minimum size delayed annual cash flows (MSDACF). Currency is in U.S. dollars.

\begin{tabular}{|c|c|c|c|c|}
\hline Treatment & Frequency & Year(s) & Amount (\$) & $\mathrm{PV}(\$)$ \\
\hline Plant tree & Single time & 0 & $(70.00)$ & $(70.00)$ \\
\hline Annual savings & Annual & $10-90$ & 13.67 & 172.84 \\
\hline Remove tree & Single time & 90 & $(406.00)$ & (5.03) \\
\hline Net present value (over 90 years) & & & & 97.81 \\
\hline UTSV (in perpetuity) & & & & 99.04 \\
\hline
\end{tabular}

Table 4. Windbreak model at a $5 \%$ interest rate illustrating minimum size delayed periodic cash flows (MSDPCF). Currency is in U.S. dollars.

\begin{tabular}{lllc}
\hline Treatment & Frequency & Year & Amount $(\$)$ \\
\hline Plant tree & Single time & 0 & $(70.00)$ \\
Wind savings & Every ten years & $15,25,35 \ldots$ & 150.00 \\
Remove tree & Single time & 90 & $(406.00)$ \\
& & & 183.11 \\
Net present value (over 90 Years) & & & $(5.03)$ \\
UTSV (in perpetuity) & & 108.08 \\
\hline
\end{tabular}

Table 5. Soil enhancement model at a $5 \%$ interest rate illustrating patterned terminating periodic series (PTPS). Currency is in U.S. dollars.

\begin{tabular}{|c|c|c|c|c|}
\hline Treatment & Frequency & Year(s) & Amount (\$) & PV $(\$)$ \\
\hline Plant & Single & 0 & $(70.00)$ & $(70.00)$ \\
\hline Fertilization & Annual & $10-30$ & 25.00 & 206.61 \\
\hline Sod/aeration & Single & 10 & $1,100.00$ & 675.30 \\
\hline Sod/aeration & Single & 30 & $1,100.00$ & 254.52 \\
\hline Fertilization & Annual & $30-90$ & 50.00 & 230.55 \\
\hline Sod/aeration & Single & 40 & $2,200.00$ & 312.50 \\
\hline Sod/aeration & Single & 50 & $2,200.00$ & 191.85 \\
\hline Sod/aeration & Single & 70 & $2,200.00$ & 72.35 \\
\hline Sod/aeration & Single & 80 & $2,200.00$ & 44.40 \\
\hline Remove tree & Single & 90 & $(406.00)$ & $(5.70)$ \\
\hline \multicolumn{4}{|c|}{ Net present value (over 90 years) } & $2,445.41$ \\
\hline \multicolumn{4}{|c|}{ UTSV (in perpetuity) } & $2,476.08$ \\
\hline
\end{tabular}


Table 6. Maintenance costs example at a $5 \%$ interest rate illustrating minimum size delayed patterned terminating cash flows (MSDPTCF). Currency is in U.S. dollars.

\begin{tabular}{|c|c|c|c|c|}
\hline Treatment & Frequency & Year(s) & Amount (\$) & $\mathrm{PV}(\$)$ \\
\hline Pruning (annual) & Annual & $20-90$ & $(160.00)$ & $(1,226.72)$ \\
\hline Pruning (minor) & Five years & $20-90$ & $(160.00)$ & $(271.40)$ \\
\hline Pruning (major) & Ten years & $20-90$ & $(260.00)$ & $(95.65)$ \\
\hline Net present value (over 90 years) & & & & $(367.05)$ \\
\hline
\end{tabular}

$\$ 160$ and major pruning occurs once every 10 years for $\$ 260$, then a calculation from Formula 9 should be used. Table 6 also illustrates this cash flow in a simple format. Note that major pruning was actually an MSDPCF of $\$ 100$ occurring once every 10 years stacked onto the MSDPCF of $\$ 160$ occurs every five years.

\section{DISCUSSION}

The types and nature of cash flows for urban tree and forest DCF or income approach valuation were described. Regular DCF formulas were described and specialized DCF formulas were developed to accommodate many of the irregular cash flows common to urban tree and forest valuation. Examples show how each formula might be used in the income approach.

DCF valuation software is in common use, including urban forestry applications. Unfortunately, most of this software contains the standard DCF formulas and requires cash flows to be one of the regular patterns (e.g., annual, terminating, perpetual, or periodic). All standard DCF formulas have rigid assumptions on cash flow structure; especially on the timing of the first payment and that payments must be uniform over time. Cash flows in urban tree and forest valuation situations often do not follow these rigid patterns, preventing appraisers and analysts from using conventional software valuation packages to solve complex problems. The income approach is a valuable tool in appraisals and valuations (Cullen 2005), and the complexity of cash flows is one of the reasons it is not used more. Plus, the income approach is valuable as supporting evidence when other approaches are used. For example, an appraisal based on comparable sales is stronger if a supplemental analysis of cash flows and the income approach support the estimated value (Appraisal Institute 2008).

These specialized DCF formulas allowed for easier use of the income approach in urban tree and forest situations. In addition, any standard forest valuation software package could be easily expanded to include urban situations by including formulas and cash flow situations in calculation options. FORVAL, for example, already includes specialized forestry situations (Bullard et al. 2011), and its format was ideal to add the type of cash flow patterns discussed in this study.

The examples were kept simple to illustrate formula use. However, complex patterns could be constructed and solved with these formulas. It would not be difficult to take any of the examples and expand them into a more realistic, complex urban tree or forest situation. The goal of the study authors was to present formulas and techniques that made the income approach easier to use in these situations, and so kept examples relatively simple in order to stress ease of use, rather than the complexity that could be included.

The study authors presented techniques that should make DCF analysis a more practical application for urban tree and forest appraisals and valuations. These techniques will find their way into relevant appraisal and valuation software. As presented, many could be easily incorporated into existing appraisal and valuation models. For example, many models are now spreadsheet-based, and adding these formulas to a spreadsheet would be a relatively simple matter. The authors expect the methodology and specialized formulas to become part of urban tree and forest appraisal and valuation software and to provide useful analytical shortcuts for these specialized situations.

Acknowledgments. This research was sponsored by the USDA Forest Service National Urban and Community Forestry Advisory Council.

\section{LITERATURE CITED}

American Forests. 2001. Urban ecosystem analysis, Atlanta Metro Area: Calculating nature. Accessed February 2011. <www.americanforests. org/downloads/rea/AF_Atlanta.pdf>

Appraisal Institute. 2008. The Appraisal of Real Estate. 13th Edition. The Appraisal Institute. Chicago, IL.

AtlantaTreeServiceAtCost.com. 2011. Get Atlanta tree services at cost now. Accessed 01/01/2011. <http://www.atlantatreeserviceatcost.com>

Bullard, S.H., and T.J. Straka. 1998. Basic Concepts in Forest Valuation and Investment Analysis. 2nd Edition. Forestry Suppliers, Inc., Jackson, MS.

Bullard, S.H., T.J. Straka, and C.B. Landrum. 2011. FORVAL. Online Forestry Investment Calculations. Mississippi State University. Accessed 01/02/2011. <http://www.cfr.msstate.edu/forval/>

Burns, R.M., and B.H. Honkala. 1990. Silvics of North America: 1. Conifers; 2. Hardwoods. USDA Forest Service, Washington, D.C.

Casey Trees and Davey Tree Expert Company. 2009. National Tree Benefit Calculator. Accessed 01/02/2010. <http://treebenefits.com/calculator>

Council of Tree and Landscape Appraisers. 2000. Guide for Plant Appraisal. 9th Edition. International Society of Arboriculture. Champaign, IL.

Cullen, S. 2005. Tree appraisal chronology of North American industry guidance. Journal of Arboriculture 31:157-162.

Gollier, C., P. Koundouri, and T. Pantelidis. 2008. Declining discount rates: Economic justifications and implications for long-run policy. Economic Policy 56:757-795.

Kanniainen, J. 2009. Can properly discounted projects follow geometric Brownian motion? Mathematical Methods of Operations Research 70:435-450.

Kaye, T.N., and D.A. Pyke. 2003. The effect of stochastic technique on estimates of population viability from transition matrix models. Ecology 84:1464-1476.

Klemperer, W.D. 1996. Forest Economics and Finance. McGraw-Hill, Inc., New York.

Martin, C.W., R.C. Maggio, and D.N. Appel. 1989. The contributory value of trees to residential property in Austin, Texas Metropolitan Area. Journal of Arboriculture 15:72-76.

McPherson, E.G., and J.R. Simpson. 2002. A comparison of municipal forest benefits and costs in Modesto and Santa Monica, California, USA. Urban Forestry and Urban Greening 1:62-74. 
McPherson, E.G. 2003. A benefit-cost analysis of ten street tree species in Modesto, California, U.S. Journal of Arboriculture 29:1-8.

McPherson, E.G. 2007. Benefit-based tree valuation. Arboriculture and Urban Forestry 33:1-11.

Novak, D.J., D.E. Crane, and J.F. Dwyer. 2002. Compensatory value of urban trees in the United States. Journal of Arboriculture 28:194-199.

Ocone, L. 2000. Ruling over the lawn in winter. Los Angeles Times, January 15, 2000. Accessed 01/02/2011. <http://articles.latimes. com/2000/jan/15/home/hm-54297>

Price, C. 2005. How sustainable is discounting? pp. 105-135. In: S. Kant and R.A. Berry (Eds.). Economics, Sustainability, and Natural Resources: Economics of Sustainable Forest Management. Springer, Amsterdam, Netherlands.

Sartoris, W.L., and N.C. Hill. 1983. A generalized cash flow approach to short-term financial decisions. Journal of Finance 38:349-360.

Straka, T.J., and S.H. Bullard. 1996. Land expectation value calculation in timberland valuation. Appraisal Journal 64(4):399-405.

Straka, T.J., and S.H. Bullard. 2002. FORVAL: Computer software package for forestry investment analysis. New Zealand Journal of Forestry 46(4):8-11.

Straka, T.J., and S.H. Bullard. 2006. An appraisal tool for valuing forest lands. Journal of the American Society of Farm Managers and Rural Appraisers 69:81-89.

Tietenberg, T., and L. Lewis. 2008. Environmental and Natural Resource Economics. 8th Edition. Addison-Wesley, Reading, PA.

Ulrich, R.S. 1984. View through a window may influence recovery from surgery. Science 224(4647):420-421.

United States Department of Labor, Bureau of Labor Statistics. 2011. Consumer price index. Accessed 01/02/2011. <www.bls.gov/cpi/ home.htm>

White, J.A., K.E. Case, D.B. Pratt, and M.K. Agee. 1998. Principles of Engineering Economic Analysis. 4th Edition. John Wiley \& Sons, New York, NY.

Wolf, K. 2004. What could we lose? The economic value of urban forests, pp. 2.1-2.8. In: A. Kenney (Ed.). Proceedings Sixth Annual Canadian Urban Forest Conference. Tree Canada Foundation. Ottawa, Ontario.

\section{Kristin S. Peterson}

Graduate Research Assistant

College of Forestry

Oregon State University

Corvallis, OR 97331, U.S.

Thomas J. Straka (corresponding author)

Professor of Forestry and Natural Resources

Clemson University

Box 340317

Clemson, SC 29634-0317, U.S.

tstraka@clemson.edu
Résumé. Les arbres urbains et les forêts ont des bénéfices et des coûts distincts qui peuvent être évalués financièrement. Bien qu'il y a des méthodes d'évaluation communément employées pour évaluer la valeur d'arbres individuels et celle des forêts urbaines, il existe aussi une méthode qui est plus difficile à utiliser en pratique et qui est l'analyse des flux futurs de trésorerie. C'est la méthode d'évaluation qui calcule le mieux la valeur de l'argent en terme de temps et qui permet une comparaison temporelle des coûts et des bénéfices. Les méthodes courantes d'évaluation du bois sont discutées en regard du contexte urbain et l'analyse des flux futurs de trésorerie est présentée comme une méthode d'évaluation supplétive viable pour évaluer les arbres urbains. Des modèles simples sont présentés qui permettent de solutionner les évaluations forestières urbaines types au moyen d'un logiciel conventionnel d'évaluation. Des exemples typiques de scénarios d'évaluation des coûts et bénéfices d'arbre urbain sont fournis, et ce avec des calculs d'évaluation des flux futurs de trésorerie en regard de la valeur présente et de la valeur nette présente au moyenne de formules spécialisées de flux futurs de trésorerie.

Zusammenfassung. Urbane Bäume und Wälder haben bestimmte Vorteile und Kosten, die monetär bewertet werden können. Während es weitverbreitete Medthoden zur Bewertung individueller Bäume und Wälder gibt, existiert noch eine in der Praxis schwierig anzu wendende Methode einer rückläufigen Geldfluß-Analyse (DCF). Dieser methodische Ansatz ist am besten geeignet, um den Zeitwert von Geld zu bestimmen und erlaubt einen temporären Vergleich von Vorteilen und Kosten. Die gegenwärtigen Holzbewertungsmethoden werden für urbane Situationen diskutiert und die DCF-Analyse ist als ein wirksames Instrument zur Bewertung von Bäumen vorgestellt. Einfache Modelle werden verwendet, die Lösungen gemäß einer DCF-konformen Waldbewertung unter Verwendung konventioneller Bewertungs-Software erlauben. Es werden Beispiele typischer urbaner Baumvorteile und Kostenszenarien vorgestellt, die mit DCF-Kalkulationen eines gegenwärtigen Wertes und einem Nettowert durchgespielt werden.

Resumen. Los bosques y árboles urbanos tienen distintos beneficios y costos que pueden ser evaluados financieramente. Mientras existen métodos comúnmente usados para valorar árboles individuales y bosques urbanos, un método que es difícil de usar en la práctica es el análisis de flujo de caja (DCF, por sus siglas en ingles). Este es el método de valoración que mayor toma en cuenta el valor del tiempo del dinero y permite una comparación temporal de beneficios y costos. Los métodos de valoración de madera actual son discutidos para situaciones urbanas y el análisis DCF es presentado como un método viable para evaluación de árboles urbanos. Se usan modelos simples que permiten la solución de valoración DCF usando paquetes de software convencionales. Los ejemplos típicos estàn provistos de escenarios de costos-beneficio del árbol urbano, con cálculos DCF de valor presente $(\mathrm{PV})$ y valor presente neto usando las fórmulas DCF especializadas. 